\title{
The history of haemophilia'
}

\author{
G. I. C. INGRAM
}

From the Department of Haematology, St Thomas' Hospital and Medical School, London SEI $7 E H$

The history of haemophilia shows the human mind attempting to define and encompass a mysterious yet fascinating phenomenon; and also the human heart responding to the challenge of repeated adversity. These responses have not remained isolated but have frequently interacted. As doctors have studied haemophilia in order to try to do more for their patients, their investigations have notably advanced our general understanding of haemostasis; and as haemophiliacs have benefited from improvements in their treatment, they have been eager to help by giving blood samples for experiments as well as in raising funds for research.

The mutation giving rise to haemophilia is probably of great age because it occurs in at least three Orders of placental mammals, the Perissodactyla (Ungulata), the Fissipedia (Carnivora), and the Anthropoidea (Primates); for haemophilia has been described in the horse (Nossel et al, 1962) and in nine breeds of dog (Field et al, 1946; Graham et al, 1949; Kaneko et al, 1967) as well as in various races of man. The Orders to which these groups belong may have been distinct from the end of the Cretaceous, say 65 million years ago; and the mutation has probably recurred independently many times, in all three, since it must be nearly lethal in the wild state. The mutation rate in man has been estimated at about $1-4 \times 10^{-5}$ (WHO, 1972).

\section{Early References}

The earliest written references to what may have been human haemophilia are attributed to Jewish writings of the 2 nd century AD. A ruling of Rabbi Judah the Patriarch exempts a woman's third son from being circumcised if his two elder brothers had died of bleeding after circumcision (Katzenelson, 1958; Rosner, 1969); and Rabbi Simon ben Gamaliel forbade a boy to be circumcised because the sons of his mother's three elder sisters had died after circumcision (Rothschild, 1882, qu. Bullock and

\footnotetext{
1Opening lecture to the Third European Regional Congress of the World Federation of Haemophilia, London, 27 April 1976, marking the Silver Jubilee of the British Haemophilia Society.
}

Fildes, 1911; Seligsohn, 1973). There are subsequent similar Rabbinic references; and these features of fatal bleeding after minor surgery in brothers or in maternally related boy cousins are characteristic of the disorder we call haemophilia. In the 10th century, males of a certain village who bled to death from trivial wounds were described by Khalaf ibn Abbas, known to us as Albucasis. In the 12th century, Maimonides applied the Rabbinic ruling to the sons of a woman who was twice married (Seligsohn, 1973); and down the years there are other scattered records of bleeding disorders more or less closely agreeing with the clinical picture we know.

The first descriptions which we may say probably do refer to haemophilia are from the end of the 18th century. Although William Hewson, despite his interest in abnormalities of the blood, does not appear to describe the disorder, the anonymous obituarist of Isaac Zoll, writing in 1791 (qu.McKusick 1962), Consbruch in 1793 and 1810, Rave in 1796 ( $q u$. Bullock and Fildes, 1911), and Otto in 1803 all described families in which males suffered abnormally prolonged post-traumatic bleeding. In the Zoll family, six brothers bled to death after minor injuries, but their half-siblings by a different mother were unaffected; in Consbruch's family, a man and two of his sister's sons were affected; Rave himself was affected, with his three brothers; and Otto noted that, although only males showed the symptoms, the disorder was transmitted by unaffected females to a proportion of their sons. Those who were affected were known as 'bleeders'. Otto, in America, traced his pedigree back to a woman, notice, named Smith who had settled near Plymouth, New Hampshire in about 1720-30. These accounts began to define a clinical syndrome on which the 19th century developed an extensive literature. Various long names were used-haemorrhoea, idiosyncrasia haemorrhagica, haematophilia, bleeding disease, hereditary haemorrhagic diathesis; our rather strange name 'haemophilia', 'love of blood', occurs in the title of Hopff's treatise of 1828.

The disorder proved as fascinating then as it does today. A description, with a full review of the literature and a clear enunciation of the singular 
mode of inheritance, was given by Nasse in 1820 . Numerous dissertations and treatises were published in the following years, and many papers in journals. Grandidier seems to have spent his life collecting and publishing compendious if somewhat uncritical data on haemophilia, his chief work being a monograph in 1855. Twenty years later came the authoritative accounts of Legg (1872) and Immermann (1879) in English and German respectively. The involvement of joints, to us the most characteristic symptom of haemophilia, was described in detail by König only in 1890; this had earlier been confused with tuberculous, rheumatic, and other types of arthritis. Some families were studied over successive generations by a series of authors; two famous kindreds are the New England family described successively by Hay in 1813, Osler in 1885, Pratt in 1908 (pedigree 408 of Bullock and Fildes, 1911), and McKusick and Rapaport in 1962; and the extensive pedigree of bleeders in the Swiss mountain village of Tenna, traced from the mid-17th century, and studied successively by Thormann (1837), Vieli (pub. anon. 1846), Grandidier (1855), and Hoessli (1885) in the 19th century, as recounted by Bullock and Fildes (1911), then by another Dr. Hoessly in 1930, and by Professor Koller's group in the 1950s (Koller, 1954).

The rare occurrence of true haemophilia in the female is supposed first to have been described by Sir Frederick Treves in 1886, from a first-cousin marriage; his family was again studied by Handley and Nussbrecher in 1935, Merskey in 1951(a), Valberg in 1959, Gilchrist in 1961, and, most recently, by Kernoff and Rizza in 1973.

My excuse for passing so quickly to the present century is of course that all the earlier history of haemophilia has been incomparably recorded by Bullock and Fildes. Their monumental monograph, published in 1911, is for students of haemophilia at once their Shakespeare for its drama and its human warmth, and their Bible for its towering authorityor at least, shall we say, their Old Testament, for in 1911 Bulloch and Fildes could really only deal with haemophilia clinically and genealogically, the Law and the Prophets so to speak; the Grace of laboratory diagnosis and blood product therapy could then be only dimly foreseen. What they did, Bulloch and Fildes did supremely well: they dealt critically with nearly 1000 references and case reports and set out over 200 pedigrees, distinguishing cases of haemophilia by sex, symptoms, and inheritance from numerous other records of unexplained bleeding. It speaks eloquently for the case mortality during the century separating them from Otto that Bulloch and Fildes retained what seems to have been his view that haemophilia could be transmitted only by the female. Evidently few affected males lived to repro- ductive age (Kerr, 1963); and Bulloch and Fildes $\stackrel{0}{\vec{\sigma}}$ lacked the clinical evidence for the obligatory carriership of haemophiliacs' daughters, which to us is so important, and remained doubtful of the diagnosiso in those families showing male transmission, even듬 though some of their pedigrees demonstrated it, $\frac{\bar{c}}{\bar{c}}$ including the Tenna kindred.

\section{The Royal Haemophilia}

However, I cannot leave Victoriana altogether without mentioning Queen Victoria herself, and the noblest haemophiliacs of them all(fig 1).It is said that Victoria was brought up from the age of 12 years to. know her destiny as the future Queen of England; but there was a part of her heritage which she could not know until after the birth of her eighth child,o 22 years later in 1853, Leopold, Duke of Albany, who was a haemophiliac. Two of her daughters also $c$ proved to be carriers, transmitting the disorder to three of her grandsons and six of her great-grand- ${ }^{\infty}$ sons. The condition is not known among any of the Queen's antecedants, so that it is supposed that a? mutation occurred at spermatogenesis in her father, Edward, Duke of Kent, a mischance perhaps made more likely by the fact that he was in his fifties when she was conceived (McKusick, 1965).

Leopold was severely affected and suffered numer- $\stackrel{\curvearrowright}{\circ}$ ous bleeding episodes. In 1868 the British Medical $\vec{F}$ Journal noted a 'severe accidental haemorrhage'응 leading to 'extreme and dangerous exhaustion by the? loss of blood' at the age of 15 . When he was 26 , the Queen wrote of him to her Prime Minister, Disraeli, that he had 'been four or five times at death's door'? and was 'never hardly a few months without being laid up' ( $q u$. Massie, 1968). At 29 he married Helen of Waldeck and died of a cerebral haemorrhage two years later (1884) after falling and hitting his head. His daughter, Alice, born the previous year, who은 became Princess of Teck, had a haemophilic son, $\rightarrow$ Rupert, Viscount Trematon, born in 1907, who died at 21 , also of a cerebral heamorrhage.

Leopold's carrier sisters were Alice, 10 years older than he was, born in 1843, and Beatrice, the baby of the family, born in 1857. Alice married Louis IV, $\omega$ the Grand Duke of Hesse; one of her sons, Frederick, died of bleeding aged 3, and two of her daughters, Irene and Alix, had haemophilic sons. Irene marriedळ her cousin, Prince Henry of Prussia; two of her ${ }^{\text {? }}$ three sons were affected, Waldemar who left no무 children although he lived to the age of 56, and Henry? who died aged 4. Alix is better known to us as? Alexandra, the consort of Tsar Nicholas II of Russia, and their son Alexis (born 1904) is presumably the world's most famous haemophiliac, and'cer- 


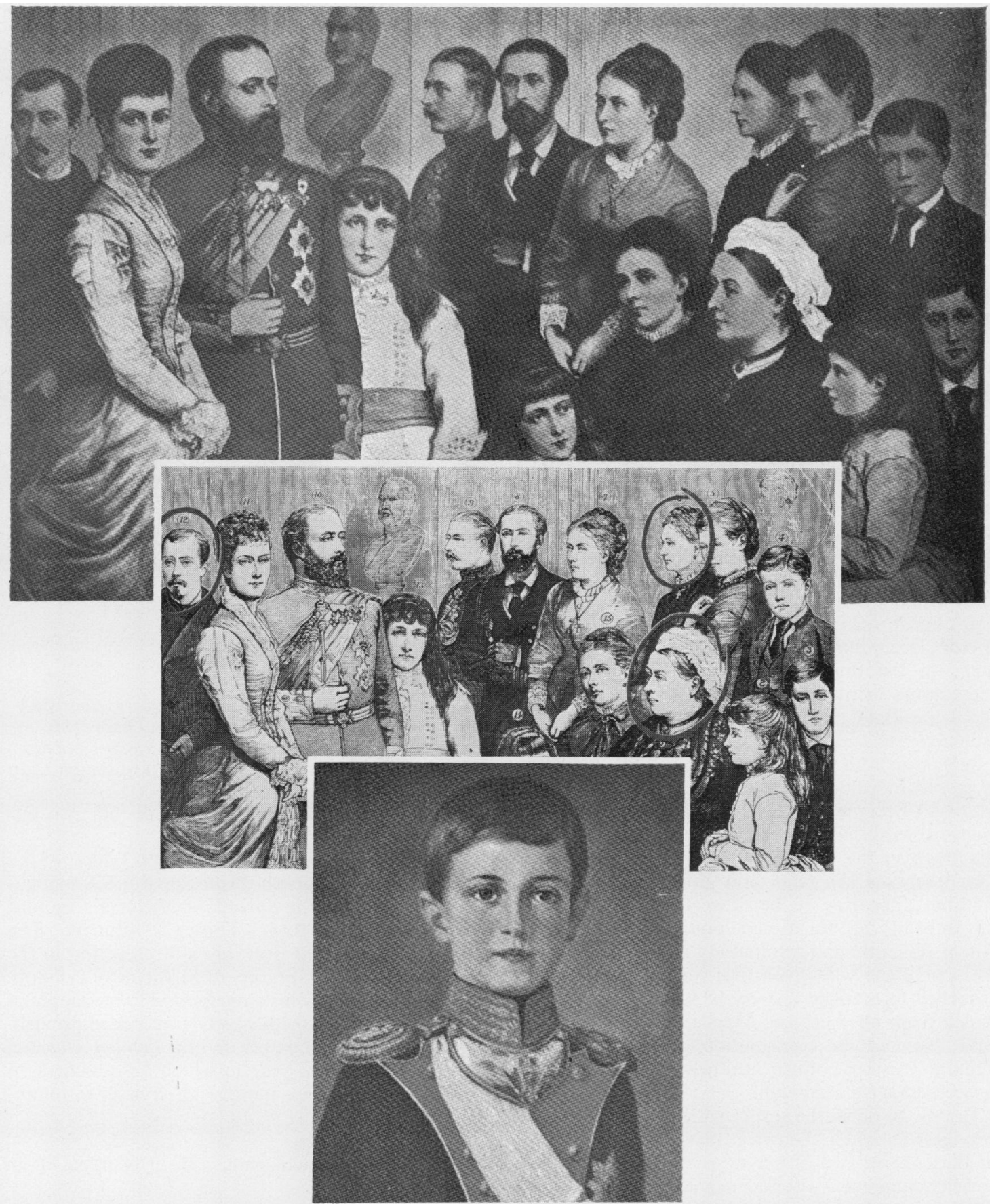

Fig. 1 Queen Victoria and her family. Victoria (circled lower right) transmitted the gene to her son Leopold (circled) and to two daughters, one of whom, Princess Beatrice, is depicted (upper right). Prince Alexis (below) was Victoria's great-grandson (see text).

[Reproduced by courtesy of the Mansell Collection and the Nursing Times.] 
tainly one of the most tragic (fig 2). Through Dorothy L. Sayers' (1932) novel Have his Carcase, and, more importantly, R. K. Massie's (1968) book Nicholas and Alexandra, and the film version made for Columbia Pictures by Sam Spiegel, many people now know the story of the Romanov haemophilia. One passage from Massie's book well illustrates the mental as well as the physical anguish generated in the Imperial household, and also emphasizes the painfulness of extravasated blood, which is the chief clinical burden of haemophilia. The family was on holiday at Spala when Alexis was 8 years old. He had been kept indoors for a week or two after a minor groin injury, and Alexandra decided to take him for a drive with Anna Vyrubova. 'Not long after starting, Alexis winced and began to complain of pain in his lower leg and abdomen. Frightened, the Empress ordered the driver to return to the villa immediately. There were several miles to travel. Every time the carriage jolted, Alexis, pale and contorted, cried out. Alexandra, now in terror, urged the driver first to hurry, then to go slowly. Anna Vyrubova remembered the drive as "an experience in horror. Every movement of the carriage, every rough place in the road, caused the child the most exquisite torture and by the time we reached home, the boy was almost unconscious with pain". Botkin (the doctor), examining the boy, found a severe haemorrhage in the thigh and groin.' The pain of the haematoma increased for some days and led to an agonizing illness; resolution eventually followed an exchange of telegrams with Rasputin, whose influence on both private and public affairs thereafter increased inordinately. Much later, Pierre Gilliard, who had become Alexis' tutor shortly before that incident, wrote: 'The illness of the Tsarevich cast its shadow over the whole of the concluding period of Tsar Nicholas II's reign and alone can explain it. Without appearing to be, it was one of the main causes of his fall, for it made possible the phenomenon of Rasputin and resulted in the fatal isolation of the sovereigns who lived in a world apart, wholly absorbed in a tragic anxiety which had to be concealed from all eyes' ( $q u$. Massie, 1968). Historians have disputed the contribution of Alexis' haemophilia to Russian politics, but the strain on the Royal household is clear enough.

Briefly, to finish the story of Victoria's family, her youngest daughter, Beatrice, married Prince Henry of Battenberg; two of her three sons were affected, and her daughter, Victoria Eugenie, married Alfonso XIII, the previous King of Spain. Two, and possibly three, of their five sons were haemophiliacs; there is no evidence so far that either of their daughters was a carrier. The present British Royal Family cannot of course have inherited haemophilia

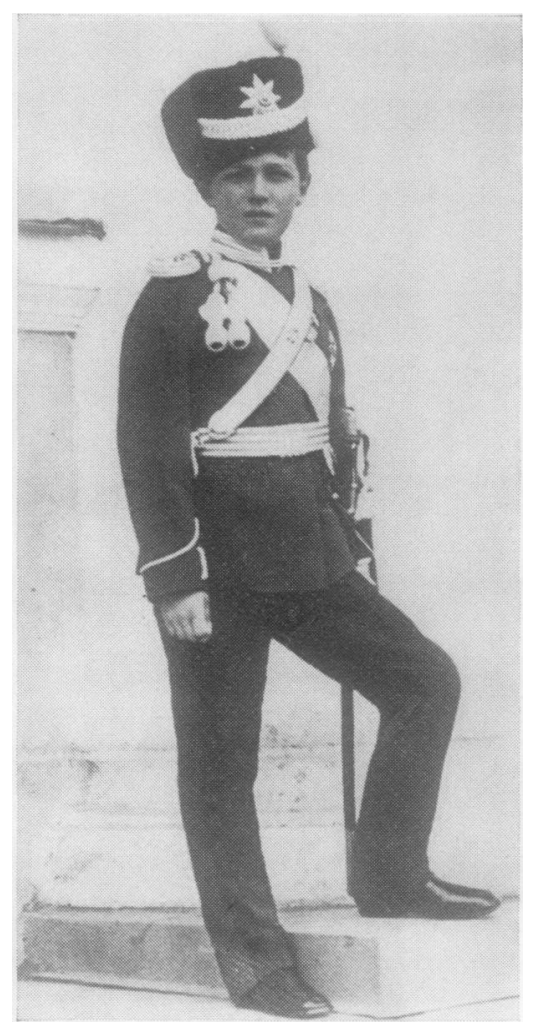

Fig. 2 The Tsarevich Alexis, aged 10 years. Note the position of the left leg with flexed hip and knee. This was probably due to previous muscle and joint bleeding. (Reproduced by courtesy of The Press Association!Ltd.)

through King Edward VII because he was unaffected.

We must return now to Bulloch and Fildes, of the monumental monograph. Professor Bulloch meticulously traced out the spread of Victoria's mutant 0 gene through the Royal houses of Europe. The family trees which he drew are still preserved in the Library of the Royal Society of Medicine of London. Sir Paul Fildes made his contribution to haemophilia of largely while still a medical student, indeed publish- N ing an independent paper in the London Hospital $N$ Gazette in 1909, the year in which he qualified. In later years he became famous, of course, in microbiology (Gladstone et al, 1973).

The Concept of Haemophilia-the Definition of an Idea

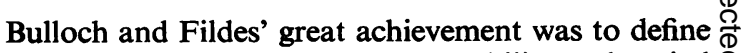
and stabilize the concept of haemophilia on the triad $\varrho$ of symptoms, sex incidence, and inheritance, and to rescue it from the confusion to which it had been 8 
subject. But definition is elusive and conceptual stability, in science, often short-lived. As new facts appear, 'Words strain', to quote the poet T. S. Eliot (1944), 'crack and sometimes break, under the burden, Under the tension, slip, slide, perish, Decay with imprecision, will not stay in place, Will not stay still'. All that remains is 'the intolerable wrestle with words and meanings'. We must now examine the impact of ideas coming from laboratory investigation, and the effect they have had on the definition of haemophilia.

Some 19th century writers thought that haemophilic bleeding was due to a vascular abnormality. However, defective blood coagulation had been noted by the 1830s (Wardrop, 1835, qu. Lane, 1840) and by the beginning of this century was established as a characteristic feature (Wright, 1893). By 1910, Addis $(1910,1911)$ was clear that it would explain the haemostatic failure. Thus, to the characteristic symptoms, sex incidence, and family history of haemophilia established clinically could be added the laboratory criterion of a long clotting time, which now became part of the definition.

Various workers began to investigate this delay in clotting. In the two decades before the first world war, Sahli (1905) found that fibrinogen was sufficient to form a substantial clot. Addis (1910, 1911), Howell (1914), and others showed that the clotting of fibrinogen by thrombin was not retarded by haemophilic blood, so this step was normal. Addis (1910, 1911) demonstrated a delay in the conversion of prothrombin to thrombin, and Howell (1914) thought that prothrombin was reduced. These conclusions were drawn from studying a plasma fraction obtained by dilution and mild acidification, which would later be called euglobulin, but which at that time was the standard method of preparing prothrombin. The gain in knowledge seemed real, and the view was unchallenged for 20 years.

Then, in 1935, A. J. Quick, studying jaundice, approached the measurement of prothrombin in a different way. According to the current theory, blood clotted because thromboplastin liberated thrombin from prothrombin in the presence of calcium ions. Thromboplastin could be prepared from tissues; and Quick argued that if thromboplastin were provided in excess, and calcium ions in optimum concentration, the clotting time of a plasma sample would then, in effect, measure its prothrombin concentration. He (Quick, 1935; Quick, StanleyBrown and Bancroft, 1935) thus devised the test we still use as Quick's 'Prothrombin Time'. Quick (1935; Quick et al, 1935) momentously found that the test gave a normal result in haemophilia: the prothrombin, after all, was normal. However, he showed that the clotting time of haemophilic plasma was markedly delayed by centrifugation to reduce its platelet count, and so his laboratory definition (Quick, 1941) included the concepts of a long blood-clotting time, a normal prothrombin time but an obvious prolongation of the plasma clotting time after spinning down the platelets.

Although we no longer think of Quick's prothrombin time test as a direct measure of prothrombin, we look back to the introduction of this test as the beginning of the modern period in blood coagulation research, because with this technique observations were made which challenged and extended the theory of clotting which had remained virtually static since the formulation of Morawitz in 1905. Compared to the early work of Consbruck, Rave and Otto, and even to the codification of Bulloch and Fildes, Quick's work is very recent; all that has followed has happened within the span of less than half a century.

But to return to haemophilia: Quick $(1940,1941)$ became convinced that the essential defect was a toughness of haemophilic platelets, preventing their breakdown and the liberation of their thromboplastin; but Patek and Stetson (1936) and others showed that normal platelets added to haemophilic plasma did not shorten the clotting time, and that haemophilic platelets worked normally in normal plasma, and the platelet contribution to haemophilic haemostasis was not much further pursued. Several other workers contributed to this controversy, but interest in haemophilic platelets largely lapsed. Recently, however, Walsh et al (1973) showed that differences in the reactivity of haemophilic platelets could be correlated with the incidence of bleeding in severely affected patients, throwing light on an aspect of the disorder which had previously been very puzzling. Meanwhile another line of study had developed. Addis (1911), in Edinburgh, had shown that the addition of a small proportion of his 'prothrombin' preparation made from normal blood would markedly correct the prolonged clotting of haemophilic blood. Twenty years later, in Belgium, Govaerts and Gratia (1931) refined these observations by demonstrating that the correcting fraction of the normal plasma was not absorbed by a Berkefeld filter or by tricalcium phosphate: it could not therefore really be prothrombin. However, it was a large molecule because it was not filterable through a collodion membrane. Five years later, Patek and Taylor (1937) at Harvard re-examined the fraction precipitated from normal plasma by dilution and mild acid which, you remember, Addis had worked with, and which they now called a 'globulin'; they confirmed that a small proportion would markedly correct the clotting of haemophilic blood. With other colleagues, Taylor later (Lewis et al, 
1946) called this fraction 'anti-haemophilic globulin', which we have since abbreviated to 'AHG'. In due course, attempts were made to assess the level of AHG in the blood of patients. In the early 1950s, Merskey and Macfarlane (1951) in Oxford measured the clotting times of the blood to be tested, when serially diluted in the blood of a haemophiliac; and Graham et al (1951) in Chapel Hill, North Carolina, used the rate of prothrombin conversion as a measure. Numerous improvements were later suggested, and eventually the precise statistical apparatus of bioassay (Finney, 1952), largely developed by pharmacologists and in the vitamin trade (Coward, 1947; Burn et al, 1950), was brought to bear (Ingram, $1965)$ and of course has now been computerized (Williams et al, 1975).

All this work allowed haemophilia to be redefined round the central feature of a reduction in antihaemophilic globulin. To avoid confusion with other names which have been proposed we now usually refer to 'factor VIII', the Roman numeral by which this clotting factor has been designated by international agreement (Wright, 1962). We could therefore say that a male patient could be diagnosed as a haemophiliac provided there was reasonable evidence of a life-long bleeding tendency and that a factor-VIII assay showed a definite reduction. The definition therefore no longer depended on a positive family history, the position taken by Bulloch and Fildes. Even the long whole-blood clotting time was no longer obligatory, for it became apparent, especially from the work of Merskey $(1950,1951 b)$ at Oxford, that milder degrees of haemophilia existed in which the clotting time was normal but posttraumatic bleeding was nevertheless typically prolonged. We could therefore think of haemophilia simply as a sex-linked, recessive coagulation disorder due to a deficiency of factor VIII. However, there has been yet another twist in the course of events. In 1971, Ratnoff and his colleagues (Zimmerman et al, 1971) described immunological experiments in which they had prepared a rabbit antiserum to human factor VIII derived from normal subjects. They were able to obtain a single precipitin line against normal factor VIII, and demonstrated that the factor-VIII activity was neutralized by the antibody. However, when they tested haemophilic plasma, with no factor VIII activity, they still obtained a precipitin line. This work has been widely confirmed, and so we must redefine haemophilia yet again as a sex-linked, recessive coagulation disorder in which the biological activity of factor VIII is reduced because the factorVIII molecule, though in some sense present, is functionally impaired. There are obvious analogies with protein abnormalities in other fields, for instance the haemoglobin variants; and work is going on in many centres to elucidate the nature of the abnormality in haemophilia. There has been a welcome bonus in this work in the detection of female carriers of haemophilia. Carrier women synthesize a mixture of normal and abnormal factor VIII, so that the rabbit antibody assay reads about twice as high as the bioassay; and the ratio between the two results seems to detect carriers more efficiently than bioassay alone (Zimmerman et al, 1971).

The immunological study of haemophilia is closely linked with that of von Willebrand's disease. In 1926 , von Willebrand described a hereditary bleeding disorder affecting both sexes among the inhabitants of the Aland Islands in the mouth of the Gulf of Bothnia, in which also the bleeding time was prolonged. Further investigation suggested that the bleeding was due to a platelet abnormality (von Willebrand and Jürgens, 1933) although later (Blackburn, 1961), capillary abnormalities were described. A similar clinical disorder had been noted in America by Minot (1928). Von Willebrand's disease had seemed quite distinct from haemophilia because of the autosomal, dominant inheritance, both sexes being equally affected and transmission being predominantly through affected persons, and because of the long bleeding time which was seldom found in classical haemophilia. It was therefore with great surprise, in the 1950s, that a reduction in factor VIII was found to occur also in von Willebrand's disease (Alexander and Goldstein, 1953; Larrieu and Soulier, 1953; Jürgens et al, 1957; Nilsson et al, 1957). It was most interesting to find that Ratnoff's antibody (Zimmerman et al, 1971) did not detect excess factor VIII-like antigen in the plasma of patients with von Willebrand's disease; the antibody measurement was similar to the biological activity of factor VIII. Now it has been found that the antigen is normally synthesized in vascular endothelium, but not in at least some cases of severe von Willebrand's disease; it has therefore been suggested again, on this new evidence, that von Willebrand's disease is indeed a vascular abnormality (Caen and Sultan, 1975). Clearly, haemophilia and von Willebrand's disease must be due to different genetic defects, because of the difference in the inheritance, yet in both disorders the same clotting factor is affected, though apparently in a different way. The current problems are therefore both biochemical and genetic, and are very fascinating although the picture is still rather confused.

There is another important distinction to be made from haemophilia, which illustrates an alternative approach to definition. Suppose two blood samples both show a long clotting time, and they are mixed together and the clotting time shortens; then it may be inferred that they have different defects, because 
each has supplied something which the other lacked. If, on the other hand, they do not correct each other like this, but are nevertheless each corrected by normal blood, then they have the same defect. Thus a haemophiliac may be defined as a male, etc. whose blood does not correct the clotting defect when mixed with the blood of a known haemophiliac. This is of course no more than the application of a wellknown principle in the descriptive biological sciences, determination by comparison with a type specimen; and it was used in this field as early as 1938 by Joules and Macfarlane. However, in 1944, Pavlovsky in Buenos Aires (Castex et al, 1944; Pavlovsky, 1947) described mutual correction on mixing the blood of two haemophiliacs. He explained his findings another way and did not realize the implication which we now see. Then in 1952, Aggeler and others in San Francisco, Biggs, Macfarlane and their colleagues in Oxford, and Schulman and Smith in New York described a condition clinically and genetically similar to haemophilia but due to a different defect-in a previously undescribed clotting component now known as factor IX, producing the condition known in the British literature as Christmas disease, named after the original Oxford patient, who was actually a Canadian. The Oxford paper appeared in the Christmas number of the British Medical Journal; and early in the new year a seriousminded correspondent from Leeds railed against such levity. In defence, the Oxford authors pointed out that the name they had chosen was somewhat simpler than a possible descriptive epithet, "hereditary hypocoprothromboplastinogenaemia', and more modest than a seven-part eponym; and they were at pains to forestall any attempt to name the possible precursor, 'Christmas Eve factor' (Biggs et al, 1953a).

This work was associated at Oxford with major advances in the theoretical study of blood coagulation (Biggs et al, 1953b, 1953c) and had wide repercussions, as shown, for instance, in a symposium organized the next year in the American journal Blood entitled 'What is hemophilia?', containing contributions by the major contestants. William Dameshek's editorial complained that haemophilia might no longer be what it seemed; 'Aggeler's hemophilia-like disease . . . caught the eye,' he wrote, 'and Macfarlane's probably identical "Christmas disease" dazzled it'. People had begun to wonder, 'what actually is hemophilia?'. It transpired, incidentally, that the famous Tenna kindred has Christmas disease and not haemophilia in the modern sense after all (Koller, 1954). Again, the word 'haemophilia' strained and cracked under the tension, and Eliot's 'intolerable wrestle' had to be taken up again.

\section{The Treatment of Haemophilia}

The United States Surgeon General's Catalogue first includes a section on the treatment of haemophilia in a volume of the Second Series published in 1901; the listed titles mention the administration of lime, the inhalation of oxygen, and the use of thyroid gland or of bone marrow, of hydrogen peroxide or gelatin. In the corresponding volume of the next series, published in 1926, there is an even longer list of miscellaneous treatments, including the injection of sodium citrate, calcium lactate or of Witte's peptone, anaphylaxis, splenectomy, and the 'galvanic needle'. Various sera were injected, both animal and human, including some from a child's mother. In two cases at least, antidiphtheritic serum was used. Adrenaline is mentioned in a paper dated 1904. Even in the Fourth Series volume of 1942, the reported treatments are still depressingly miscellaneous; the application of bird's muscle jostles with $x$-ray irradiation and autohaemotherapy; 'tissue fibrinogen' is given by mouth, and anaphylaxis is induced by passive sensitization. There is much written on female hormone therapy (in the belief that femininity prevents the expression of the haemophilic gene). Oxalic acid is injected intravenously, and there are two books and several papers on vitamin therapy. Blood is both injected and withdrawn therapeutically.

To this period belongs also the Timperley treatment with a bromide extract of egg white (Timperley et al, 1936) which a number of haemophiliacs have believed to have helped them, and some still do. Nevertheless, most of these treatments must have been based on little more than guess-work; and their general ineffectiveness is testified to by the extensive morbidity and early mortality recorded in stark detail by Carol Birch (1937) in her classic monograph published 40 years ago, differing little from the natural history of the disease in the 19th century (Kerr, 1963). One of the first treatments to be based on sound experimental work was the topical application of coagulant snake venom. In 1934, R. G. Macfarlane began to study the effects of snake venoms on haemophilic blood at the suggestion, he says (Macfarlane, 1965, 1967), of the physiologist, Hartridge, who died this year. Macfarlane found (Macfarlane and Barnett, 1934) that the venom of Russell's Viper clotted haemophilic blood rapidly, and moreover could do so in less than a minute when diluted in the blood up to 1 in 1000000 and so was eminently suitable as a local application, for which it has been much used.

The key to modern treatment was of course the development of blood transfusion. The earliest record of its use in haemophilia is probably Lane's (1840) 
account of the direct transfusion of 12 ounces of blood from a 'stout young woman' to an 11-year-old boy who had bled for six days after an operation for squint. After the transfusion the bleeding stopped and the boy recovered. The Third Series of the Surgeon General's List (1926) was the first to carry a separate section on blood transfusion in the treatment of haemophilia, containing 12 references. By 1938, Macfarlane had appreciated that only blood transfusion offered effective treatment for a bleeding episode, no doubt by replacing temporarily a missing essential component. The description of antihaemophilic globulin mentioned earlier of course fitted in here, and when Christmas disease was distinguished from haemophilia it was clearly seen that specific blood products should be used in the treatments of different defects. It also became apparent that early cases of spontaneous bleeding into joints and muscles would respond adequately to an intravenous infusion of plasma, but that for major trauma more activity must be given than the patient's circulation could accept as whole plasma, which provided further stimulus to the preparation of concentrates. Following the work of Cohn, human preparations of factor VIII were developed in the 1950s in Britain (Kekwick and Wolf, 1957), France (Soulier, Gobbi and Larrieu, 1957) and Sweden (Blombäck, Blombäck and Nilsson, 1958), and concentrates from animal blood were also prepared (Macfarlane et al, 1954; Bidwell, 1955a, b). Experience was gradually accumulated on the use of blood products in dental extraction and in progressively more daring surgery as patients presented with injuries or other conditions requiring extensive treatment. The story has been vividly told for Oxford by Biggs (1967) in a contribution to the issue of the British Journal of Haematology which commemorated Professor R. G. Macfarlane's 60th birthday. One important group of operations which could now be undertaken was for the orthopaedic correction of the numerous disabilities caused by previous bleeding into joints and muscles. The advances made possible may be seen by comparing the slower and patient manipulation of the 1950 s described by Jordan (1958) in his classic monograph, Hemophilic Arthropathies, with the vigorous surgical approach of Duthie, Matthews, Rizza and Steel (1972) in their corresponding modern book.

A noteworthy development in blood product therapy followed the observation which Professor Judith Pool reported in 1965 (Pool and Shannon, 1965), that on slowly thawing frozen plasma much of the factor-VIII activity remained with the fibrinogen sludge which was slow to redissolve. This so-called 'cryoprecipitate' could be spun down and so re-frozen for storage, and the supernatant plasma re-associated with the red cells of the blood donation from which it was derived, thus reconstituting the pint of blood for other use. This simple procedure has been widely adopted by transfusion services to provide a supply of antihaemophilic material for routine treatment.

The supply of freeze-dried concentrates is now steadily improving, and we are beginning to see the logical extension whereby patients treat themselves promptly by intravenous injection of factor VIII preparations which they keep at home.

The medical management of haemophilia has been operated from specially designated haemophilia centres, in Britain first set up in the early 1950s as diagnostic centres, particularly to make the precise haematological diagnoses of haemophilia and Christmas disease, and to issue haemophilia identity cards, and becoming treatment centres as knowledge grew and facilities increased. There are now some 50 centres in the British Isles. The scheme was initiated by the combined efforts of the Medical Research Council and the Ministry of Health under the aegis of a joint Haemophilia Committee following an enquiry by Sir Weldon Dalrymple-Champneys at the Ministry in 1950. A Medical Research Council Memorandum described the diagnosis and treatment of haemophilia (Macfarlane and Biggs, 1955), and a second edition has now been published (Biggs, 1974). Through the National Health Service it has been possible to make antihaemophilic treatment available throughout the country wherever there are personnel trained to administer it.

Thus we have reached the point where we can effectively treat episodes of spontaneous haemophilic bleeding, and we can prevent abnormal bleeding after trauma or surgery. For the unfortunate $10 \%$ of haemophiliacs who have produced an anti-VIII antibody, and so defy the usual treatment, factor-IX concentrates have begun to be used (Kurczynski and Penner, 1974). Preventive treatment is still in the very early stages; and of course we still cannot cure the disorder. Nevertheless the human mind continues to respond to the challenge of haemophilia, and no doubt a cure will come.

\section{Haemophilia Societies and the World Federation of Hemophilia}

A far greater challenge of course confronts the haemophiliac himself; and I must briefly recount the Toynbeean response which this has elicited. No doubt individual haemophiliacs have always accepted their limitations with the courage and resourcefulness which I so admire in the haemophiliacs I know myself. However, in recent years, collective action has become possible. 
In this country, haemophiliacs first seem to have gathered together in the 1930s when many came to be tested by R. G. Macfarlane and to obtain his Russell's Viper venom. He and J. B. S. Haldane were in touch over the inheritance of colour blindness in haemophiliacs (Bell and Haldane, 1937), and no doubt it was through this contact that about half a dozen haemophiliacs, under one of Macfarlane's original patients, began to meet in the Francis Galton Laboratory for National Eugenics at University College where Haldane worked, by arrangement with Professor Penrose, to see whether something could be done. In 1942, patients and sympathizers formed a group known as the International Haemophilia Society; and it seems that they made contact with about 100 haemophiliacs in the early days. There was no formal membership at first, no subscription, and of course no offices or headquarters organization; but in the early post-war years communication was established with Sir Weldon Dalrymple-Champneys at the Ministry of Health. In 1950 the Society was registered with the London County Council as a charity-still as the 'International Haemophilia Society'; and that year also saw the Ministry of Health's first conference on haemophilia. During this period the Society was allowed to hold its committee meetings at the Hospital for Sick Children, Great Ormond Street, and a close association has since been maintained. The Society's first offices were at the old headquarters of the Fire Brigade in Southwark. The first financial assistance from an outside source was a grant from the Halley Stewart Trust, which was continued with an annual sum for a number of years. In 1953 the late Dr. E. Neumark, of St. Mary's Hospital, joined the committee as the Society's first medical adviser. In 1954 the Society participated in discussions at the Ministry of Health on the setting up of haemophilia centres and on problems of education, employment, transport, and fund raising. In the same year the Society was renamed 'The Haemophilia Society' and reorganized and reconstituted with Rules and Regulations. Sir Lionel Whitby became the Society's first President, and in the following year presided at the first annual general meeting and the first council meeting held under the new Rules, which provided for representation of various Ministries at meetings of the council; local groups of the Society were formed, and membership increased throughout the country. In 1957 Sir Weldon Dalrymple-Champneys succeeded to the Presidency after the death of Sir Lionel Whitby. In the early 1960s the membership passed the $\mathbf{1 0 0 0}$ mark and included the friends and families of haemophiliacs as well as the patients themselves. In 1964 the medical advisory panel was formed. In 1965 the Society conducted a major survey on the education, employment, and social welfare of haemophiliacs by questionnaire among its affected members over 17 years of age; 503 questionnaires were returned out of 640 distributed, and three notable reports were prepared (Haemophilia Society, 196769). In 1971 the Society's research appeal for $£ 50000$ was launched and achieved in two years; most of this money was distributed to haemophilia centres for buying equipment and other research needs. In 1972 Her Royal Highness the Duchess of Kent graciously consented to become the Patron of the Society. In 1973 the Society appointed its own medical social worker. It now includes about 1500 haemophiliacs among its members, and it has a mailing list of about 2000 in this country and of a further 250 overseas.

Similar societies have been formed in other countries; and in 1963 our Society was a founder member of the World Federation of Hemophilia. Relationships with WHO and other international bodies have been formed, a dozen International World Federation meetings have been held at which the haemophiliacs have been hosts and their doctors their scientific guests, some 20 international haemophilia training centres have been set up, and the number of national haemophilia societies and groups affiliated to the World Federation has now reached about 40. A directory of national treatment centres has been produced as a Guide for Travelling Hemophiliacs. This is a remarkable record of self help, in which haemophiliacs themselves have largely participated despite their own disabilities. It is particularly interesting how haemophiliacs and their doctors have come to work together in both research and administration to promote the advancement of knowledge as well as the relief of suffering.

Finally, some words of Professor Macfarlane $(1965,1967)$ from his delightful paper on the story of Russell's Viper venom: 'The main value of [a historical story] is that one sees how the growth of knowledge is hampered by prejudice and the failure to recognise one's own ignorance, as well as by the misuse of words and the mixing up of facts and theories. Having seen that, one resolves to do better in the future.'

I should like to express my indebtedness to the Librarian of the Royal Society of Medicine and to Mrs Geoffrey Rickman for their help with the early literature; and to Sir Weldon Dalrymple-Champneys, Professor R. G. Macfarlane, FRS, the Chairman and Officers of the British Haemophilia Society, Mr Clive Knight, and all others who have helped me in preparing this lecture, which was first given before the Section on the History of Medicine of the Royal Society of Medicine, London on 1 May 1974. 


\section{References}

Addis, T. (1910). Hereditary haemophilia: deficiency in the coagulability of the blood the only immediate cause of the condition. Quart. J. Med., 4, 14.

Addis, T. (1911). The pathogenesis of hereditary haemophilia. J. Path. Bact., 15, 427.

Aggeler, P. M., White, S. G., Glendening, M. B., Page, E. W., Leake, T. B., and Bates, G. (1952) Plasma thromboplastin component (PCT) deficiency: a new disease resembling hemophilia. Proc. Soc. exp. Biol. (N.Y), 79, 692

Alexander, B. and Goldstein, R. (1953). Dual hemostatic defect in pseudohemophilia. J. clin. Invest., 32, 551 .

Bell, J. and Haldane, J. B. S. (1937). The linkage between the genes for colour-blindness and haemophilia in man. Proc. roy. Soc. $B, 123,119$.

Bidwell, E. (1955a). The purification of bovine antihaemophilic globulin. Brit. J. Haemat., 1, 35.

Bidwell, E. (1955b). The purification of antihaemophilia globulin from animal plasma. Brit. J. Haemat., 1, 386.

Biggs, R. (1967). Thirty years of haemophilia treatment in Oxford. Brit. J. Haemat., 13, 452.

Biggs, R (1974). Haemophilia and its related conditions: a brief guide to diagnosis and treatment. Memor. med. Res. Coun. (Lond.), No. 44.

Biggs, R., Douglas, A. S., and Macfarlane, R. G. (1953a). Christmas disease. Brit. med. J., 1, 221.

Biggs, R., Douglas, A. S., and Macfarlane, R. G. (1953b). The formation of thromboplastin in human blood. $J$. Physiol. (Lond.), 119, 89.

Biggs, R., Douglas, A. S., and Macfarlane, R. G. (1953c). The initial stages of blood coagulation. J. Physiol. (Lond.), 122, 538.

Biggs, R., Douglas, A. S., Macfarlane, R. G., Dacie, J. V., Pitney, W. R., Merskey, C. and O'Brien, J. R. (1952). Christmas disease: a condition previously mistaken for haemophilia. Brit. med. J., 2, 1378.

Birch, C. La F. (1937). Hemophilia, Clinical and Genetic Aspects. University of Illinois, Urbana.

Blackburn, E. K. (1961). Primary capillary haemorrhage (including von Willebrand's disease). Brit. J. Haemat., 7, 239.

Blombäck, B., Blombäck, M., and Nilsson, I. M. (1958). Note on the purification of human antihemophilic globulin. Acta chem. scand., 12, 1878.

British Medical Journal (1868). Prince Leopold, 1, 125.

Bulloch, W. and Fildes, P. (1911). Treasury of Human Inheritance, Parts V and VI, Section XIVa, Haemophilia. Also published as Eugenics Laboratory Memoirs XII, Francis Galton Laboratory for National Eugenics, University of London (UCH), London. Dulau and Co. Ltd., 37 Soho Square, London.

Burn, J. H., Finney, D. J , and Goodwin, L. G. (1950). Biological Standardization, 2nd edition. Oxford University Press, London.

Caen, J. P., and Sultan, Y. (1975). von Willebrand disease as an endothelial-cell abnormality. Lancet, 2, 1129.

Castex, M. R., Pavlovsky, A., and Simonetti, C. (1944). Contribución al es dio de la fisiopatogenia de lau hemofilia. Med. B. Aires, 5, 16.

Consbruch, G. W. (1793; 1810). Cited by Bulloch and Fildes (1911).

Coward, K. H. (1947). The Biological Standardization of the Vitamins, 2nd edition. Baillière, Tindall and Cox, London.

Duthie, R. B., Matthews, J. M., Rizza, C. R., and Steel, W. M. (1972). The Management of Musculo-skeletal Problems in the Haemophilias. Blackwell, Oxford.

Eliot, T. S. (1944). Four Quartets. Faber and Faber, London.

Field, R. A., Rickard, C. G., and Hutt, F. B. (1946). Hemophilia in a family of dogs. Cornell Vet., 36, 285.
Fildes, P. (1909). Haemophilia. London Hosp. Gaz., 16, 48.

Finney, D. J. (1952). Statistical Methods in Biological Assay. Griffin, London

Gilchrist, L. (1961). A female case of haemophilia. Proc. roy. Soc. Med., 54, 813.

Gladstone, G. P., Knight, B. C. J. G., and Wilson, G. (1973). Paul Gordon Fildes. Biogr. mem. Fel. roy. Soc., 19, 317.

Govaerts, P. and Gratia, A. (1931). Contribution a l'étude de l'hémophilie. Rev. Belge. sci Med., 3, 689.

Graham, J. B., Buckwalter, J. A., Hartley, L. J., and Brinkhous, K. M. (1949). Canine hemophilia, J. exp. Med., 90, 97.

Graham, J. B., Penick, G. D., and Brinkhous, K. M. (1951). Utilization of the antihemophilic factor during clotting of canine blood and plasma. Amer. J. Physiol., 164, 710.

Grandidier, L. (1855). Die Hämophilie, oder die Bluterkrankheit. Leipzig.

Haemophilia Society (1967a). Survey of adult haemophiliacs. 1. Employment and unemployment.

Haemophilia Society (1967b). Survey of adult haemophiliacs. 2. Social welfare.

Haemophilia Society (1969). Survey of adult haemophiliacs. 3. Education.

Handley, R. S. and Nussbrecher, A. M. (1935). Hereditary pseudohemophilia. Quart. J. Med., 4, 165.

Hay, J. (1813). Cited by Bulloch and Fildes (1911).

Hoessli (1885). Cited by Bulloch and Fildes (1911).

Hoessly, G. T. (1930). Der Stammbaum der Bluter von Tenna. Julius Klaus-Stiftung, 5, Heft 3/4.

Hopff, F. (1828). Cited by United States Surgeon General's Catalogue, 1st series, Haemophilia.

Howell, W. H. (1914). The condition of the blood in haemophilia. Amer. J. Physiol., 33, 13.

Immermann, H. (1879). Cited by Bulloch and Fildes (1911).

Ingram, G. I. C. (1965). Advances in Clinical Chemistry, edited by $\mathrm{H}$. Sobotka and C. P. Stewart, pp. 222-236. Academic Press, New York.

Jordan, H. H. (1958). Hemophilic Arthropathies. Thomas, Springfield, Illinois.

Joules, H. and Macfarlane, R. G. (1938). Pseudo-haemophilia in a woman. Lancet, 1,715 .

Jürgens, R., Lehmann, W., Wegelius, O., Eriksson, A. W., and Hiepler, E. (1957). Mitteilung über den Mangel an antihämophilem Globulin (Faktor VIII) bei der Aaländischen Thrombopathie (v. Willebrand-Jürgens). Thrombos. Diathes. haemorrh. (Stuttg.), 1, 257.

Kaneko, J. J., Cordy, D. R., and Carlson, G. (1967). Canine hemophilia resembling classic hemophilia A.J. Amer. vet. med. Ass., 150, 15.

Katzenelson, J. L. (1958). Hemophilia with special reference to the Talmud. Hebrew med. J., 1, 165.

Kekwick, R. A. and Wolf, P. (1957). A concentrate of human antihaemophilic factor-its use in six cases of haemophilia. Lancet. 1, 647.

Kernoff, P. B. A. and Rizza, C. R. (1973). Factor-VIIIrelated antigen in female haemophilia. Lancet, $2,734$.

Kerr, C. B. (1963). The fortunes of haemophiliacs in the nineteenth century. Med. Hist.. 7, 359.

Koller, F. (1954). Is hemophilia a nosologic entity? Blood, 9, 286.

König, F. (1890-94). Cited by Bulloch and Fildes (1911).

Kurczynski, E. M., and Penner, J. A. (1974). Activated prothrombin concentrate for patients with factor VIII inhibitors. New Engl. J. Med., 291, 164.

Lane, S. (1840). Successful transfusion of blood. Lancet, 1, 185.

Larrieu, M. J. and Soulier, J. P. (1953). Déficit en facteur antihémophilique $\mathbf{A}$ chez une fille, associé à un trouble du saignement. Rev. Hémat., 8, 361.

Legg, J. W. (1872). A Treatise on Haemophilia sometimes 
called the Hereditary Haemorrhagic Diathesis, p. 158. H. K. Lewis, London.

Lewis, J. H., Tagnon, H. J., Davidson, C. S., Minot, G. R., and Taylor, F. H. L. (1946). The relation of certain fractions of the plasma globulins to the coagulation defect in hemophilia. Blood, $1,166$.

Macfarlane, R. G. (1938). Thesis for the degree of MD, University of London. Cited by Biggs (1967).

Macfarlane, R. G. (1965). Russell's Viper venom, 1934-64. Oxford med. Sch. Gaz., 17, No. 3.

Macfarlane, R. G. (1967). Russell's Viper Venom, 1934-64, reprinted in Brit. J. Haemat., 13, 437.

Macfarlane, R. G. and Barnett, B. (1934). The haemostatic possibilities of snake venom. Lancet, $2,985$.

Macfarlane, R. G. and Biggs, R. (1955). The diagnosis and treatment of haemophilia and its related conditions. Memor. med. Res. Coun. (Lond.), No. 32.

Macfarlane, R. G., Biggs, R., and Bidwell, E. (1954). Bovine antihaemophilic globulin in the treatment of haemophilia. Lancet, 1, 1316.

McKusick, V. A. (1962). The earliest record of hemophilia in America? Blood, 19, 243.

McKusick, V. A. (1965). The royal hemophilia. Sci. Amer., 213, 88.

McKusick, V. A. and Rapaport, S. I. (1962). History of classical hemophilia in a New England family. Arch. intern. Med., 110, 144.

Massie, R. K. (1968). Nicholas and Alexandra. Gollancz, London.

Merskey, C. (1950). The laboratory diagnosis of haemophilia. J. clin. Path., 3, 301.

Merskey, C. (1951a). The occurrence of haemophilia in the human female. Quart. J. Med., 20, 299.

Merskey, C. (1951b). Haemophilia associated with normal coagulation time. Brit. med. J., 1, 906.

Merskey, C. and Macfarlane, R. G. (1951). The female carrier of haemophilia: a clinical and laboratory study. Lancet, 1, 487.

Minot, G. R. (1928). A familial hemorrhagic condition associated with prolongation of the bleeding time. Amer. J. med. Sci., 175, 301.

Morawitz, P. (1905). Die Chemie der Blutgerinnung. Ergebn. Physiol., 4, 307.

Nasse (1820). Cited by Bulloch and Fildes (1911).

Nilsson, I. M., Blombäck, M., and von Francken, I. (1957). On an inherited autosomal hemorrhagic diathesis with antihemophilic globulin (AHG) deficiency and prolonged bleeding time. Acta med. scand., 159, 35.

Nossel, H. L., Archer, R. K., and Macfarlane, R. G. (1962). Equine haemophilia: report of a case and its response to multiple infusions of heterospecific AHG. Brit.J. Haemat., 8, 335.

Osler, W. (1885). Cited by Bulloch and Fildes (1911).

Otto, J. C. (1803). An account of an hemorrhagic disposition existing in certain families. Med. Repos., 6, 1.

Patek, A. J. and Stetson, R. P. (1936). Hemophilia. The abnormal coagulation of the blood and its relation to the blood platelets. J. clin. Invest., 15, 531.

Patek, A. J. and Taylor, F. H. L. (1937). Hemophilia. Some properties of a substance obtained from normal human plasma effective in accelerating the coagulation of hemophilic blood. J. clin. Invest., 16, 113.

Pavlovsky, A. (1947). Contribution to the pathogenesis of hemophilia. Blood, 2, 185.

Pool, J. D. and Shannon, A. E. (1965). Production of high potency concentrates of antihemophilic globulin in a closed bag system. New Engl J. Med., 273, 1443.

Pratt, J. H. (1908). Cited by Bulloch and Fildes (1911).

Quick, A. J. (1935). The prothrombin in hemophilia and in obstructive jaundice. J. biol. Chem., 109, 23.

Quick, A. J. (1940). A classification of hemorrhagic diseases due to defects in the coagulation mechanism of the blood. Amer. J. med. Sci., 199, 118.

Quick, A. J. (1941). The diagnosis of hemophilia. Amer. J. med. Sci., 201, 469.

Quick, A. J., Stanley-Brown, M., and Bancroft, F. W. (1935). A study of the coagulation defect in hemophilia and in jaundice. Amer. J. med. Sci., 109, 501.

Rave, A. (1796). Cited by Bulloch and Fildes (1911)

Rosner, F. (1969). Hemophilia in the Talmud and Rabbinic writings. Ann. intern. Med, 70, 833.

Sahli (1905). Cited by Addis (1910).

Sayers, D. L. (1932). Have His Carcase, chapter 34. Gollancz, London.

Schulman, I. and Smith, C. H. (1952) Hemorrhagic disease in an infant due to deficiency of a previously undescribed clotting factor. Blood, 7, 794.

Seligsohn, U. (1973). Hemophilia and other clotting disorders. Israel J. med. Sci., 9, 1338.

Soulier, J. P., Gobbi, F., and Larrieu, M. J. (1957). Séparation du fibrinogène et du facteur antihémophilique A. Rev. Hemat., 12, 481.

Timperley, W. A., Naish, A. E., and Clark, G. A. (1936). A new method of treatment in haemophilia. Lancet, 2 , 1142.

Treves, F. (1886). A case of haemophilia, pedigree through five generations. Lancet, 2, 533.

Valberg, L. S. (1959). Haemophilia A in a 'girl' with male sex-chromatin pattern. Lancet, 2, 466.

Walsh, P. N., Rainsford, S. G., and Biggs, R. (1973). Platelet coagulant activities and clinical severity in haemophilia. Thrombos. Diathes. haemorrh. (Stuttg.), 29, 722.

Wardrop (1835). Cited by Lane (1840).

Willebrand, E. A. von (1926). Hereditäre Pseudohemofili. Finska Làk.-Sàllsk. Handl., 68, 87.

Willebrand, E. A. von and Jürgens, R. (1933). Über ein neues vererbbares Blutungsübel: die konstitutionelle Thrombopathie. Dtsch. Arch. klin. Med., 175, 453.

Williams, K. N., Davidson, J. M. F., and Ingram, G. I. C. (1975). A computer program for the analysis of parallelline bioassays of clotting factors. Brit. J. Haemat., 31, 13.

Wright, A. E. (1891). Upon a new styptic and upon the possibility of increasing the coagulability of the blood in the vessels in cases of haemophilia and aneurysm and internal haemorrhage. Brit. med. J., 2, 1306.

Wright, A. E. (1893). On a method of determining the condition of blood coagulability for clinical and experimental purposes and on the effect of the administration of calcium salts in haemophilia and actual or threatened haemorrhage. Brit. med. J., 2, 223.

Wright, 1. S. (1962). The nomenclature of blood clotting factors. Thrombos. Diathes. haemorrh. (Stuttg.), 7, 381.

World Health Organization (1972). Inherited blood clotting disorders. Wld. Hlth. Org. techn. Rep. Ser., No. 504, p. 14.

Zimmerman, T. S., Ratnoff, O. D., and Littell, A. S. (1971). Detection of carriers of classic hemophilia using an immunologic assay for antihemophilic factor (factor VIII). J. clin. Invest., 50, 255.

Zimmerman, T. S., Ratnoff, O. D., and Powell, A. E. (1971). Immunologic differentiation of classic hemophilia (factor VIII deficiency) and von Willebrand's disease. J. clin. Invest., 50, 244. 